\title{
Analisis Kebijakan Penyertaan Modal Pemerintah Daerah Terhadap Kinerja Perusahaan Umum Daerah Air Minum Pancuran Telago Kabupaten Bungo
}

\author{
Sri Wineh \\ Dosen Program Studi Akuntansi, Fakultas Ekonomi, Universitas Muara Bungo \\ sriwineh0205@gmail.com
}

\begin{abstract}
Abstrak
Penelitian ini bertujuan untuk mengetahui seberapa besar penyertaan modal Pemerintah Daerah Kabupaten Bungo Kepada Perusahaan Daerah Air Minum Pancuran Telago dan untuk mengetahui dampak dari penyertaan modal Pemerintah Daerah Kabupaten Bungo terhadap kinerja Perusahaan Daerah Air Minum Pancuran Telago. Objek penelitian adalah Perusahaan Daerah Air Minum Pancuran Telago Kabupaten Bungo , dengan periode penelitian lima tahun yaitu tahun 2015 sampai dengan tahun 2019. Teknik pengumpulan data dengan metode observasi, wawancara dan dokumentasi. Teknis analisa data dalam penelitian ini menggunakan metode kuantitatif dengan menggunakan rumus kinerja keuangan yaitu Return On Equity , Rasio operasi, cash rasio dan efektivitas penagihan. Hasil penelitian ini menunjukan bahwa jumlah penyertaan modal Pemerintah Daerah Kabupaten Bungo Kepada Perusahaan Daerah Air Minum Pancuran Telago terus mengalami peningkatan sampai dengan tahun 2016, untuk tahun 2017 sampai dengan tahun 2019 mengalami penurunan. Sementara dampak dari penyertaan modal terhadap kinerja perusahaan terlihat pada rasio Return On Equity, Rasio operasi, cash rasio untuk efektivitas penagihan belum memberikan pengaruh.
\end{abstract}

Kata Kunci : Penyertaan Modal, Kinerja Perusahaan

\section{Policy Analysis Of Investment Policy Of Regional Governments On The Performance Of Regional General Companies In Pancuran Telago Drinking Water, Bungo Distric}

\begin{abstract}
This study aims to determine how much the equity participation of the Local Government in Telago Pancuran Water Supply Company and to determine the impact of the local goverment capital participation on the performance of the Telago Pancuran Water Supply Company. The object of research is the Telago Pancuran Water Supply Company, with a research period of five years, namely 2015 to 2019. The data collection technique uses observation, interview and documentation methods. The data analysis technique in this research uses quantitative methods using financial performance formulas, Return on Equity, operating ratios, cash ratios and billing effectiveness. The results of this study indicate that the amount of equity participation of the local Government to the Telago Pancuran Water Company continues to increase until 2016, for 2017 to 2019 it has decreased. Meanwhile, the impact of equity participation on company performance can be seen in the Return on Equity ratio, operating ratio, cash ratio for collection effectiveness.
\end{abstract}

Keyword: Equity Participation, Performance 


\section{PENDAHULUAN}

Perusahaan Daerah Air Minum (PDAM) merupakan salah satu perusahaan milik daerah kabupaten dan daerah kota yang bergerak di bidang pengelolaan dan penyediaan air bersih. Dalam menjalankan usaha PDAM merupakan perusahaan yang tidak hanya berorientasi pada pelayanan masyarakat, tetapi juga berorientasi dalam menghasilkan laba. Laba yang dihasilkan oleh perusahaan sebagian digunakan untuk kegiatan operasional perusahaan dan sebagian lagi disetor ke pemerintah guna meningkatkan pendapatan asli daerah. Akan tetapi kenyataanya sebagian besar PDAM mengalami kerugian sehingga belum mampu berkontribusi terhadap pendapatan asli daerah.

Pemerintah melalui Kementerian Pekerjaan Umum dan Perumah-an Rakyat (PU-Pera) berkomitmen menyediakan akses air bersih yang mudah bagi seluruh masyarakat di Indonesia. Hal itu diwujudkan dengan memprioritaskan sektor tersebut. Dari total anggaran sebesar Rp110 triliun, Kementerian PU-Pera menyalurkan Rp32 triliun untuk Direktorat Jenderal Sumber Daya air (SDA). Dalam RPJMN (Rencana Pembangunan Jangka Menengah Nasional/RPJMN), ada program 100-0-100, dan baru tercapai Baru 72\% sampai 2019 ini. Program 100-0-100 yang dimaksud adalah bagaimana akses air minum terpenuhi untuk masyarakat tercapai $100 \%$, lalu bagaimana kawasan kumuh itu hilang hingga target $0 \%$, serta bagaimana sanitasi lingkungan terpenuhi dengan baik (100\%).

Pemerintah daerah seharusnya dapat meningkatkan pendapatan asli daerahnya untuk membiayai aktivitas operasionalnya. Bila suatu daerah dapat membiayai program dan kegiatannya dari pendapatan asli daerah, maka daerah tersebut bisa dikatakan daerah yang sudah mandiri, karena daerah tersebut tidak bergantung pada dana perimbangan dan pendapatan transfer dari pemerintah pusat maupun provinsi. Pemerintah harus memperhatikan ataupun segera menindak lanjuti PDAM yang berstatus kurang sehat dan yang sakit agar kebutuhan masyarakat akan air bersih dapat terpenuh, Muhammad Nur (2020)

Dalam susunan Pendapatan Asli Daerah Badan Usaha Milik Daerah memiliki peranan dalam mengisi komponen Pendapatan Asli Daerah, yang merupakan pendapatan yang di dapat dari bagian laba penyertaan modal yang di lakukan pemerintah daerah. Pengelolaan penyertaan modal pemerintah daerah jika diwujudkan dalam bentuk investasi yang produktif pada suatu perusahaan daerah akan menciptakan tingkat pengembalian yang produktif dan efektif. Hal ini apabila dilakukan dengan menekan biaya operasional dan non operasional (efisien), meningkatkan pendapatan/penjualan, dan melakukan investasi produktif yang pada akhirnya akan meningkatkan kinerja keuangan. Kondisi tersebut dapat terjadi apabila tata kelola terhadap penyertaan modal untuk pertumbuhan aktiva, penciptaan efisiensi dan peningkatan kinerja keuangan dapat dilakukan dengan konsisten oleh manajemen BUMD,(Mario Adi Wibowo, 2017).

Permasalahan PDAM kabupaten Bungo tidak jauh beda dengan permasalahan PDAM yang ada di seluruh Indonesia, yaitu masih rendahnya kinerja yang di lihat dari laba yang diperoleh perusahaan, dimana PDAM kabupaten Bungo masih selalu merugi. Permasalahan terkait kinerja PDAM pada umumnya terjadi pada kinerja pelayanan, yakni masih terdapat keluhan-keluhan dari masyarakat/pelanggan terkait pelayanan yang belum maksimal. Hal serupa juga terjadi pada PDAM Pancuran Telago Kabupaten Bungo, dimana masyarakat bungo khususnya pelanggan PDAM masih belum menikmati pelayanan air selama 24 jam, bahkan masih ada wilayah yang belum memiliki jaringan pipa sehingga cakupan pelayanan untuk wilayah kabupaten Bungo masih di kategorikan rendah yakni masih mencapai $17 \%$. Secara umum penyebab dari belum maksimalnya pelayanan PDAM terhadap pelanggan adalah masih tingginya tingkat kehilangan air sehingga hal ini berdampak pada kinerja perusahaan. Kondisi sarana dan prasarana juga merupakan penyebab lain mengapa pelayanan masih begitu rendah, dimana sarana dan prasarana yang dimiliki oleh PDAM kabupaten Bungo sudah melewati usia teknis sehingga tidak bisa optimal untuk di manfaatkan.

Perkembangan terbaru adalah ketika pemerintah akhirnya mengeluarkan regulasi yang berkaitan dengan BUMD, yaitu Peraturan Pemerintah (PP) No. 54 Tahun 2017 Tentang BUMD. Pada pasal 92 tentang Tata Kelola Perusahaan Yang Baik, secara tegas menyatakan bahwa BUMD harus mengelola perusahaan dengan melaksanakan asas transparansi. Dari uraian di atas maka dapat di rumuskan masalah berapa jumlah dan bagaimana dampak dari penyertaan modal Pemerintah Daerah Kabupaten Bungo terhadap kinerja Perusahaan Daerah Air Minum (PDAM)?

\section{TINJAUAN PUSTAKA}

Kinerja Perusahaan

Dalam melakukan evaluasi terhadap kinerja perusahaan salah satu sumber informasi yang bisa digunakan adalah informasi dalam laporan keuangan. Salah satu komponen Laporan keuangan yang sering digunakan dalam mengevaluasi kinerja adalah laporan laba rugi. Laba sering kali digunakan sebagai ukuran 
kinerja atau sebagai dasar dalam perhitungan rasio profitabilitas. Unsur laporan laba rugi yang berkaitan dengan kinerja perusahaan adalah penghasila (income) dan Beban (Expense)

\section{Return On Equity}

Rasio ini digunakan untuk melihat seberapa besar kemampuan perusahaan dalam menghasilkan laba dari modal yang dimiliki oleh perusahaan. Rasio ini sangat penting, mengingat keuntungan yang memadai diperlukan untuk mempertahankan arus sumbersumber modal perusahaan.

\section{Rasio Operasi}

Rasio operasi merupakan rasio yang dapat mengukur tingkat efisiensi perusahaan yang disebabkan oleh besarnya biaya operasi dalam setiap penjualan aktivanya. Rasio operasi digunakan untuk mengevaluasi margin laba dari ativitas operasi. Rasio operasi dihitung dari penjualan dibagi dengan total biaya. Rasio juga merupakan gabungan pendapatan bersih dikurangi dengan pendapatan investasi bersih yang diperoleh

\section{Cash Rasio}

Rasio likuiditas merupakan rasio yang digunakan untuk mengukur kemampuan perusahaan dalam memenuhi kewajiban finansial jangka pendek yang berupa utang-utang jangka pendek. Rasio lancar menunjukan kemampuan perusahaan dalam memenuhi kewajiban lancarnya dengan aktiva lancarnya. "Rasio lancar untuk perusahaan yang normal berkisar pada angka 2,00. Rasio ini paling akurat dalam mengukur kemampuan perusahaan untuk memenuhi kewajiban jangka pendek karena hanya memperhitungkan komponen aktiva lancar yang paling likuid.

\section{Efektivitas Penagihan}

Menurut Mahmudi (2010) dalam Budiantoro, hermungingsih dan Wiyono (2020) efektivitas adalah hubungan antara output dengan tujuan, semakin besar kontribusi / sumbangan output terhadap pencapaian tujuan, maka semakin efektif organisasi, program atau kegiatan. Efektivitas penagihan digunakan untuk mengukur hubungan antara hasil penagihan dengan tujuan atau target yang telah ditetapkan.

\section{Penyertaan Modal}

Penyertaan modal pada BUMD merupakan bagian dari investasi jangka panjang daerah dimana jumlah akumulatifnya disajikan dalam Neraca pada sisi Aset. Dalam penganggarannya, penyertaan modal atau investasi ini tidak diakui sebagai belanja, namun dimasukkan sebagai pengeluaran pembiayaan. Di sisi lain, hasil yang diterima dari investasi yang telah dilakukan dikategorikan sebagai PAD. Penyertaan modal pemerintah Daerah merupakan penyertaan modal Pemerintah Daerah Kabupaten Bungo yang diberikan kepada Perusahaan Daerah Air Minum Pancuran Telago Kabupaten Bungo, melalui mekanisme penetapan Peraturan Daerah Penyertaan Modal. Bentuk dari penyertaan modal tersebut dapat berupa uang, barang dan peralatan serta aset tetap.

\section{METODE PENELITIAN}

Objek penelitian adalah Perusahaan Daerah Air Minum Pancuran Telago Kabupaten Bungo. Jenis dan sumber data yang digunakan dalam penelitian ini adalah data kuantitatif. Sumber data yang digunakan dalam penelitian berupa data primer, dimana data primer diperoleh langsung dari informan dan data sekunder, dimana data tersebut berupa data yang tertulis yaitu dokumen dokumen meliputi laporan keuangan perusahaan. Teknik pengumpulan data yang digunakan berupa observasi, wawancara, dan dokumentasi. Teknik analisis data yang digunakan yaitu dengan analisis kuantitatif, dimana analisis terhadap penelitian yang dapat memberi gambaran dan keadaan perusahaan pada masa lalu yang digambarkan melalui laporan keuangan. Rumus teknik analisis data yang digunakan berdasarkan teknik analisis Pengukuran kinerja PDAM antara lain:
a. $\quad$ Return On Equity = Laba (Rugi) setelah pajak
b. $\quad$ Rasio Operasi $=\quad$ Biaya Operasi Jumlah Equitas$$
\text { Pendapatan Operasi }
$$
c. Cash Ratio $=\underline{\text { Kas }+ \text { setara kas }}$ Utang Lancar
d. Efektivitas Penagihan $=\underline{\text { Jumlah Penerimaan air }}$ Jumlah Rekening Air 
e. $\quad$ Penyertaan Modal = besarnya penyertaan modal pemerintah daerah pada tahun $\mathrm{t}$

\section{HASIL DAN PEMBAHASAN}

Perusahaan Daerah Air Minum Pancuran Telago Kabupaten Bungo merupakan Badan Usaha Milik Pemerintah Kabupaten Bungo yang didirikan berdasarkan Peraturan Daerah Kabupaten Bungo Nomor 2 tahun 1993 yang di sahkan dengan keputusan Gubenur Jambi nomor 212 tahun 1993 tanggal 27 Mei 1993. Tahun 2019 PDAM Pancuran Telago berdasarkan Peraturan Daerah Nomor 10 tahun 2019 tanggal 21 Oktober 2019 telah berubah bentuk hokumnya menjadi Perusahaan Umum Daerah (Perumda) Air Minum Pancuran Telago atau di sebut Perumda Air Minum Pancuran Telago. Bentuk hokum tersebut diatas sudah sesuai dengan Peraturan Pemerintah nomor 54 tahun 2017 tentang Badan Usaha Milik Daerah.

Tujuan dirikannya Perusahaan Umum Daerah (Perumda) Air Minum Pancuran Telago adalah:

a. Menyediakan pelayanan kepada masyarakat sesuai dengan lingkup usahanya

b. Mendorong pertumbuhan perekonomian daerah

c. Memperoleh laba dan / atau keuntungan sebagai salah satu sumber peningkatan Pendapatan Asli Daerah

Perusahaan Umum Daerah (Perumda) Air Minum Pancuran Telago mempunyai tugas pokok menyelenggarakan pengelolaan air minum dalam rangka meningkatkan kesejahteraan masyarakat yang mencakup aspek ekonomi, kesehatan, sosial dan pelayanan umum. Dalam menjalankan usaha Perusahaan Umum Daerah (Perumda) Air Minum Pancuran Telago telah di evaluasi kinerjanya oleh Badan Pengawasan Keuangan dan Pembangunan Perwakilan Jambi. Berikut data kinerja perusahaan dari tahun 2015 sampai dengan tahun 2019.

Tabel 1. Data Kinerja Keuangan Perusahaan Daerah Air Minum Pancuran Telago Kabupaten Bungo

\begin{tabular}{|c|c|c|c|c|c|c|}
\hline \multirow[b]{2}{*}{ Tahun } & \multicolumn{4}{|c|}{ Ukuran } & \multirow{2}{*}{$\begin{array}{c}\text { Total } \\
\text { Kinerja }\end{array}$} & \multirow[b]{2}{*}{ Penyertaan Modal } \\
\hline & ROE & $\begin{array}{c}\text { Rasio } \\
\text { Operasi }\end{array}$ & $\begin{array}{l}\text { Cash } \\
\text { Ratio }\end{array}$ & $\begin{array}{l}\text { Efektivitas } \\
\text { Penagihan }\end{array}$ & & \\
\hline 2015 & $(3,23)$ & 1,13 & 0,10 & 93,35 & 97,81 & $1.500 .000 .000,00$ \\
\hline 2016 & $(0,03)$ & 1,08 & 0,45 & 89,57 & 91,13 & $52.004 .880 .716,00$ \\
\hline 2017 & $(4,56)$ & 1,12 & 7,05 & 88,47 & 101,20 & $943.615 .028,00$ \\
\hline 2018 & 1,37 & 1,20 & 69,16 & 84,97 & 156,70 & 0,00 \\
\hline 2019 & 0,30 & 1,12 & 66,34 & 82,33 & 150,09 & $5.000 .000 .000,00$ \\
\hline Rata -rata & & & & & & \\
\hline
\end{tabular}

Sumber: data diolah, 2020

\section{Besar Penyertaan Modal Pemerintah Daerah kepada PDAM Pancuran Telago Kabupaten Bungo}

Dalam upaya peningkatan kinerja perusahaan daerah, Pemerintah Daerah sebagai pemilik perusahaan dapat memberikan bantuan finansial, salah satunya melalui penyertaan modal. Pengeluaran Pemerintah Daerah yang dicatat sebagai penyertaan modal dicantumkan dalam Anggaran Pendapatan dan Belanja Daerah (APBD) dan dalam pelaksanaan penyertaan modal ke perusahaan daerah di buatkan Peraturan Daerah tersendiri yang mengatur tentang mekanisme penyertaan modal tersebut. Penyertaan modal Pemerintah Daerah kepada Perusahaan Daerah dapat dilaksanakan dan di anggarkan dalam Anggaran Pendapatan dan Belanja Daerah (APBD) apabila jumlah yang akan disertakan dalam tahun anggaran berkenaan telah ditetapkan dalam Peraturan Daerah tentang penyertaan modal daerah.

Penyertaan modal Pemerintah Daerah merupakan bagian dari investasi dalam bentuk pemberian modal, baik penyertaan modal awal maupun penambahan modal untuk upaya peningkatan kemampuan perusahaan dalam melakukan kegiatan operasionalnya, Muhammad Nur, 2020. Semakin besar penyertaan modal pemerintah daerah ke perusahaan daerah maka akan meningkatkan kinerja perusahaan. Berdasarkan Peraturan Daerah Kabupaten Bungo Nomor 15 tahun 2014 tentang Penyertaan Modal Pemerintah Daerah Kabupaten Bungo kepada Perusahaan Daerah Air Minum Pancuran Telago, bahwa pemerintah daerah telah mengalokasikan penyertaan modal sebesar Rp. 55.948.495.744,00 , dana penyertaan modal tersebut di alokasikan dari tahun 2014 sampai dengan tahun 2015 sebesar Rp. 1.500.000.000,00 pada tahun 2016 di alokasikan sebesar Rp. 52.004.880.716,00 dan pada tahun 2017 di alokasikan sebesar Rp. 943.615.028,00. Pada tahun 2018 sampai dengan tahun 2019 pemerintah daerah tidak mengalokasikan penyertaan modal ke 
Perusahaan Daerah Air Minum Pancuran Telago, namun pemerintah daerah mengalokasikan subsidi biaya operasional kepada Perusahaan Daerah Air Minum Pancuran Telago masing-masing sebesar Rp. 1.800.000.000,00 dan Rp. 1.000.000.000,00. Tujuan penyertaan modal pemerintah daerah ke Perusahaan Daerah Air Minum Pancuran Telago seperti yang tercantum pada Peraturan Daerah pada umumnya adalah untuk peningkatan kinerja perusahaan, melalui peningkatan likuiditas, solvabilitas, profitabilitas dan peningkatan pelayanan.

Penyertaan modal tahun 2015 sebesar Rp.1.500.000.000,00 di serahkan ke PDAM dalam bentuk dana tunai, dan telah di manfaatkan dengan optimal untuk:

- Pembayaran angsuran ke 2 tunggakan pokok hutang jangka panjang kepada Pmerintah Pusat sebesar Rp. 300.000.000,00

- Pembayaran tagihan rekening listrik dan Bahan Bakar sebesar Rp. 1.200.000.000,00

Penyertaan Modal tahun 2016 sebesar Rp. 52.004.880.716,00 , dan dimanfaatkan oleh Perusahaan Daerah Air Minum Pancuran Telago untuk:

- $\quad$ Sebesar Rp. 2.100.000.000,00 berupa dana tunai dan di manfaatkan untuk operasional perusahaan

- Sebesar Rp. 49.904.880.715,24 berupa hibah non tunai dan dimanfaatkan untuk pembayaran hutang jangka panjang kepada pemerintah pusat

Penyertaan Modal tahun 2018 sebesar Rp. 943.615.028,00 di serahkan dalam bentuk dana tunai dan dimanfaatkan oleh Perusahaan Daerah Air Minum Pancuran Telago untuk operasional perusahaan.

\section{Pengaruh Penyertaan Modal Pemerintah Daerah terhadap Kinerja PDAM Pancuran Telago Kabupaten Bungo}

Sebagaimana telah di jelaskan sebelumnya bahwa tujuan dari penyertaan modal Pemerintah Daerah kabupaten Bungo ke Perusahaan Daerah Air Minum Pancuran Telago adalah untuk peningkatan kinerja perusahaan yang nantinya akan berdampak pada pelayanan yang di rasakan oleh masyarakat Bungo khususnya pelanggan PDAM kabupaten Bungo. Dari tabel 1 dapat disimpulkan hubungan antara penyertaan modal pemerintah daerah terhadap kinerja secara keseluruhan mengalami peningkatan dari tahun 2015 sampai dengan tahun 2018 dan mengalami penurunan pada tahun 2019. Kinerja perusahaan jika di lihat dari rasio laba terhadap ekuitas atau Return On Equity (ROE) terus mengalami peningkatan dari tahun 2015 sampai dengan tahun 2019. Dari Hal ini di sebabkan pada tahun 2015 sampai dengan tahun 2017 kerugian perusahaan mengalami penurunan dan pada tahun 2018 dan tahun 2019 perusahaan dalam kondisi laba. Jika dihubungkan dengan penyertaan modal maka dapat di jelaskan bahwa pada tahun 2015 ke tahun 2016 adanya peningkatan jumlah penyertaan modal dan rasio laba terhadap equitas juga meningkat, walaupun perusahaan masih dalam kondisi merugi namun kerugian tersebut semakin menurun dan jumlah ekuitas bertambah karena adanya penambahan penyertaan modal oleh pemerintah daerah. Pada tahun 2017 ke tahun 2018 jumlah penyertaan modal menurun namun rasio laba terhadap equitas tetap meningkat hal ini di sebabkan oleh perusahaan dari kondisi merugi pada tahun 2017 menjadi laba pada tahun 2018. Pada tahun 2018 dan tahun 2019 perusahaan daerah air minum pancuran telago tidak menerima penyertaan modal dari pemda namun pemerintah daerah memberikan subsidi biaya operasional.

Kinerja perusahaan dilihat dari rasio operasi, yaitu biaya operasi terhadap pendapatan operasi dalam kondisi yang cukup stabil artinya perubahan dari tahun ke tahun tidak terlalu signifikan. Hal ini di karenakan selisih pendapatan operasi dan biaya operasi tidak terlalu besar, peningkatan pendapatan operasi selalu diikuti oleh peningkatan biaya operasi. Penyebab besarnya biaya operasi di karenakan :

- Biaya operasional listrik yang masih tinggi dikarenakan pompa penggerak untuk mengalirkan air ke pelanggan sudah melebihi usia teknis sehingga tidak optimal beroperasi dan memakan energi listrik yang cukup tinggi.

- Besarnya biaya pemeliharaan karena sebagian besar sarana dan prasarana mengalami kerusakan karena usia teknis

- Masih tingginya tingkat kehilangan air sehingga konsumsi air oleh pelanggan masih di bawah rata-rata sehingga hal ini berdampak pada penjualan air.

Jika dihubungkan dengan jumlah penyertaan modal dapat di simpulkan bahwa pemberian penyertaan modal pemerintah daerah terhadap perusahaan memberikan dampak terhadap laba karena sebagian besar penyertaan modal tersebut di manfaatkan untuk membayar hutang jangka panjang kepada 
pemerintah pusat. Selama ini beban bunga hutang jangka panjang membebani keuangan perusahaan sehingga perusahaan selalu mengalami kerugian.

Kinerja perusahaan dilihat dari rasio kas dimana dari tahun 2015 sampai dengan tahun 2019 mengalami peningkatan hal ini di karenakan jumlah kas dari tahun ke tahun mengalami peningkatan. Penambahan modal oleh pemerintah daerah dalam bentuk dana tunai sangat membantu perusahaan dalam memenuhi kewajiban jangka pendek perusahaan.

Kinerja perusahaan jika dilihat dari efektivitas penagihan dari tahun 2015 sampai dengan tahun 2019 cenderung mengalami penurunan, hal ini di sebabkan oleh masih belum maksimalnya penerimaan perusahaan atau piutang yang terus meningkat. Dalam hal ini perusahaan masih belum maksimal dalam mengelola piutang. Besarnya piutang perusahaan di sebabkan oleh beberapa hal sebagai berikut:

1. Kurangnya kesadaran masyarakat dalam hal ini pelanggan dalam membayar kewajiban

2. Masih belum optimalnya pelayanan perusahaan sehingga membuat pelanggan enggan untuk memenuhi kewajiban

3. Terbatasnya sarana dan prasarana perusahaan dalam mengelola piutang, misalnya perusahaan belum mampu memanfaatkan kemajuan teknologi karena minimnya modal.

Penyertaan modal pemerintah daerah terhadap Perusahaan dalam hal ini belum memberikan dampak karena penyertaan modal yang di berikan oleh pemerintah dimanfaatkan oleh perusahaan hanya sebatas untuk membantu mengurangi beban opersional perusahaan dan belum sepenuhnya dimanfaatkan untuk investasi, sehingga terhadap efektivitas penagihan belum di rasakan manfaatnya.

\section{KESIMPULAN DAN SARAN}

Penyertaan modal Pemerintah Daerah Kabupaten Bungo terhadap Perusahaan Daerah Air Minum Pancuran Telago Kabupaten Bungo menunjukan jumlah yang meningkat dari tahun 2015 ke 2016, menurun pada tahun 2017 dan 2018 kemudian meningkat kembali pada tahun 2019. Dampak dari penyertaan modal Pemerintah Daerah Kabupaten Bungo terhadap Perusahaan Daerah Air Minum Pancuran Telago Kabupaten Bungo terhadap kinerja perusahaan dapat dilihat dari rasio laba terhadap equitas, rasio operasi dan rasio kas namun belum berdampak terhadap efektivitas penagihan.

Berdasarkan hasil penelitian di atas maka penulis memberikan saran berikut:

a. Pemerintah daerah dalam memberikan penyertaan modal sebaiknya melakukan kajian investasi dan mempelajari historis perusahaan sehingga penggunaan penyertaan modal dapat termanfaatkan sesuai dengan kebutuhan perusahaan dalam hal peningkatan kinerja perusahaan.

b. Perusahaan daerah Air Minum Pancuran Telago Kabupaten Bungo perlu untuk meningkatkan kinerja yang belum baik dan memanfaatkan bantuan pemerintah daerah baik itu dalam bentuk penyertaan modal maupun subsidi untuk peningkatan kinerja perusahaan.

c. Bagi peneliti selanjutnya, diharapkan penelitian ini dapat menjadi acuan dalam penelitian yang berkaitan dengan topic yang sama yaitu pengaruh penyertaan modal pemerintah daerah terhadap kinerja perusahaan daerah air minum.

\section{DAFTAR PUSTAKA}

Amdanata, D. D., Yusriadi, Mansor, N., \& Nuzilah, N. (2019). Implementasi Asas Transparansi Good Corporate Governance pada BUMD di Indonesia. Inovbiz: Jurnal Inovasi Bisnis, 7, 154-161.

Anoraga, P. (2020). Analisis Penyertaan Modal PT. PDAM Di Kota X. ECONBANK: Journal of Economics and Banking, 2(2), 148-156. https://doi.org/10.35829/econbank.v2i2.105

Ansari, M. I. (2020). Entitas Badan Usaha Milik Daerah Setelah Berlakunya Undang- Undang Pemerintah Daerah. Kanun Jurnal Ilmu Hukum, 22(3), 417-436.

Budiantoro, A. H., Hermuningsih, S., \& Wiyono, G. (2020). Pengaruh Return On Equity, Rasio Operasi, Dan Cash Ratio Terhadap Tingkat Kesehatan Keuangan Yang Dimoderasi Oleh Penyertaan Modal dan Efektivitas Penagihan (Studi pada PDAM Bantul Tahun 2009-2019). Jurnal Bisman (Bisnis \& Manajemen): The Journal Of Business and Management, 3(2018), 111-124.

Dawu, L. M. T., \& Manane, D. R. (2020). Analisis Kinerja Keuangan Pada Perusahaan Daerah Air Minum 
(Pdam) Tirta Lontar Kabupaten Kupang. Jurnal Inspisari Ekonomi (IE), 2(3), 1-11.

Herdiyani Manafe, P. (2015). Kabupaten Pasuruan Dengan Menggunakan Perspektif Finansial Dan Non Finansial. Fakultas Ekonomi Jurusan Akuntansi Universitas Islam Negeri (UIN) Maulana Malik Ibrahim Malang.

Idrus, I. (2017). Analisis kinerja keuangan pada Koperasi Tirta Dharma Perusahaan Daerah Air Minum kota Pekanbaru. Economos: Jurnal Ekonomi Dan Bisnis, 1(April), 57-65. Retrieved from https://journal.uir.ac.id/index.php/valuta/article/view/2082

Kadafi, M., Dhanny, O., \& Wahyuni, D. (2020). Pengaruh Belanja Modal Dan Penyertaan Modal Pemerintah Terhadap Tingkat Kemandirian Daerah Pada Seluruh Kab/Kota Di Kalimantan Timur Tahun 2013 2017. Jurnal Eksis (Jurusan Akuntansi Politeknik Negeri Samarinda), 16(1), 1-19.

Mulyati, B., \& Mahmud, T. A. (2020). Analisis Rasio Keuangan Untuk Mengukur ( Studi Kasus pada Salah Satu BUMD Di Provinsi Banten ). Jurnal Ilmiah Akuntansi Universitas Pamulang, 8(2), 111-126.

Nur, M. (2020). Analisis Kebijakan Penyertaan Modal Pemerintah Daerah Terhadap Kinerja Perusahaan Daerah Air Minum ( PDAM ) Kota Parepare City. Economos : Jurnal Ekonomi Dan Bisnis Volume, 3, 51-56.

Octovia, M. (2020). Implikasi peraturan pemerintah nomor 54 tahun 2017 tentang BUMD terhadap penjaminan aset BUMD kepada bank. Jurnal poros hukum padjadjaran, 1(2), 303-314.

Sudarno, Idrus, M. S., Salim, U., \& Djumahir. (2011). Pengaruh Penyertaan Modal terhadap Pertumbuhan Aktiva, Efisiensi dan Kinerja Keuangan pada Badan Usaha Milik Daerah (BUMD). Jurnal Aplikasi Manajemen, 9(2), 515-524.

Wibowo, m. A. (2017). Analisis pengaruh penyertaan modal pemerintah daerah terhadap pertumbuhan aktiva, efisiensi, dan kinerja keuangan bumd di kabupaten wonosobo. Tesis STIE Widya Wiwaha Yogyakarta.

Yani, M. (2015). Pengaruh Penyertaan Modal Pemerintah Kota Dan Pemerintah Provinsi Terhadap Kinerja Keuangan Perusahaan Daerah Air Minum Tirta Kencana Samarinda. Jurnal Fakultas Ekonomi, Universitas 17 Agustus1945 Samarinda, 2014. 